Communication, technologies et développement

$6 \mid 2018$

Technologies mobiles, innovation et développement

\title{
Audiovisual and media literacy to promote local cultures
}

Audiovisual y competencia mediática para promocionar culturas locales Audiovisual e media literacy para promover culturas locais

\section{Viana Teixeira César}

\section{OpenEdition}

\section{Journals}

Electronic version

URL: https://journals.openedition.org/ctd/607

DOI: $10.4000 /$ ctd. 607

ISSN: 2491-1437

Publisher

Chaire Unesco Pratiques émergentes en technologies et communication pour le développement

Electronic reference

Viana Teixeira César, "Audiovisual and media literacy to promote local cultures", Communication, technologies et développement [Online], 6| 2018, Online since 18 December 2018, connection on 21 September 2021. URL: http://journals.openedition.org/ctd/607 ; DOI: https://doi.org/10.4000/ctd.607

This text was automatically generated on 21 September 2021.

Communication, technologies et développement 


\title{
Audiovisual and media literacy to promote local cultures
}

\author{
Audiovisual y competencia mediática para promocionar culturas locales \\ Audiovisual e media literacy para promover culturas locais
}

Viana Teixeira César

\section{Introduction}

1 Mostra Goiás is a brand of actions for the enhancement of Goiás State's local cultures. The making of documentaries and photo exhibitions strengthen community bonds and emphasize affectivity for shared places. Mediatic works also helps us to reinterpret where we live, assimilate or open a dialogue with cultures and diversities that surround us. Hence, this post-doctoral research and extension program, together with the Laboratory of Instrumental Analysis of Communication of the Autonomous University of Barcelona (UAB) and the Advanced Program in Contemporary Culture (PACC) of the Federal University of Rio de Janeiro (UFRJ), with practical development in Brazil at Pontifical Catholic University of Goiás (PUC Goiás). In three years, 87 documentaries were produced on cell phones with enough quality to be shown on television networks and in cinema circuits of Goiânia, the capital of Goiás. All the authors of the films never had previous works shown on any established media.

2 This action-research program starts with and insight, goes with the approach and insertion of creative and production teams, followed by the establishment of conceptual foundations for the definition and realization of these practices with the community. As David Tripp describes, action-investigation methodology is any process that follows a cycle in which the systematic oscillation improves training between acting on the field of practice and investigating it. We plan, implement, describe, and evaluate a change to improve practice, learning more in the process, both from practice and from the research itself (Tripp, 2005:446). 
The media experiences reported here were developed with sophomores of Journalism (ECOM) and Archeology (IGPA), and also with people from the general community of Goiânia (CAC). The public broadcast of those videos is granted by the partnerships established with PUC TV Goiás, the fifth largest State's television broadcaster, and with the public cinemas Goiânia Ouro and Cine Cultura. The exhibition spaces are given free of charge to students. At their end of the deal, the students are committed to producing material of sufficient technical quality to be aired. In addition to films, students also created six photography exhibitions on Goiana cultures, available at facebook.com/ mostragoias.

4 At the same time, one professional documentary - "Devils of Culture" - was also developed in partnership with the Catalan journalist Albert March. The film shows how the identity of the city of Tarragona reverberates with Ball de Diables, a medieval Catalan festival revived since the 1980s by the local community. The documentary seeks new angles and technical approaches to film and represent traditional festivals, such as the filmmakers joining the crowds for documenting sounds, actions, fashions, and customs. "Devils of Culture" will be screened at international film festivals and conferences on media and anthropology. The productions of a television pilot as a version of the Archdiocese of Goiânia's newspaper is also part of this research and extension program; done as completion work of the scholarship student, Father Warlen Reis. The details of these aspects of the research are not reported here because they were not produced only using mobile devices, but served as the basis for the searching for new ways of filming and self-representation of culture through audiovisual language.

5 The mobile devices available to students are the tools to produce video contents. Joint audio and image capture schemes were developed to achieve a minimum of technical quality. As well as specific processes for establishing common procedures and protocols regardless of the background or previous experience of participants. The production results demonstrate that any group of people with a minimum of systematic work can develop and broadcast products in different types of media, including traditional television, movie theaters networks or any other transmedia possibility available.

During a semester, students search about the history and basic precepts of photography, film, and television. They also train and develop techniques for creating audiovisual narratives. During the research, procedures and theories of film are applied. Since, in consonance to Nichols, we also consider that every movie is itself a documentary: "some documentaries make strong use of practices such as scripting, staging, reenactment, rehearsal, and performance that we associate with fiction." In the same way, some fiction movies use conventions that we associate with nonfiction: "such as location shooting, nonactors, handheld cameras, improvisation, found footage (footage not shot by the filmmaker), voice over commentary and natural lighting" (Nichols, 2017: xi).

7 As Tripp observes "problem-solving, for example, begins with identifying the problem, planning a solution, implementing it, monitoring it, and evaluating its effectiveness" (Tripp, 2005:446). Students are encouraged to use the production methods and grammar of classic Hollywood cinema to facilitate filming and video production schemes. Although they never filmed or edited, when watching movies from Hollywood between 1910 and 1920 , students realize that anyone holding a camera can also practice that shooting style. At the time, the filming scheme was simple: few types of framing and camera movements restricted to the right or left shifts. Most of the time, the camera stood still. 


\section{Audio+visual}

8 By studying audiovisual language foundations, students feel they can also produce films using the same imaging techniques that will soon fit efficiently into editing - a striking montage feature developed by DW Griffith and other film directors of his time. All the filming is done with natural lighting, only seeking the balance of light in the mobile device itself. There is no record with artificial light or recording studios in the production of Mostra Goiás. The places where they live are the filming scenarios. The proposal is to create films with the minimum technical resource, but efficient and available to the students - mobile phones. Each group uses at least two devices: one for capturing images and another for recording sound.

9 The "audio" and "visual" aspects are managed distinctly during research. The writing of the script and search for the soundtrack conform the "audio" part. There is an attempt to keep the text as close as possible to the local languages and accents. The video lessons also include basic concepts and practices of photography, always with the objective of achieving better image quality to reinforce the "visual" aspect. They come to understand photography as a language and medium of representation, according to the observations of Roger Scruton: "by its very nature, photography can 'represent' only through resemblance. It is only because the photograph acts as a visual reminder of its subject that we are tempted to say that it represents its subject" (in Walden, 2010:151).

Not necessarily students follow established and nominated standards for recordings but are encouraged to record and seek the best ways to tell and share stories. They take new paths and use mobile resources to capture, write, edit and broadcast audiovisual content. They have technical resources and begin to use basic protocols of traditional media production processes. Some even create their styles of shooting and editing. The freedom to use a "personal language" on videos helps to value and register accents, personal stories, memories and affections for the places and the time in which they share their lives.

11 Cinema has created new dimensions for the imaginary and the human coexistence. It promoted lifestyles, cultures, and customs by broadcasting a wide variety of films in crowded rooms as early as the 1920s. It gained sound, was transmuted into television and multiplied millions of times with the types of presentation and interactivity in today's digital environments. The discourses and imagery of politicians in the early twentieth century were based on the audiovisual and on the radio's ability to enter and occupy places in different geographical points simultaneously.

Soon came the television with its language, methods, and processes - with a high cost of production. There was the resource, it was already possible to record sounds and images, create ambiances, spread cultures and discourses - but few had the economic and technical means to produce films and TV programs or even maintain a movie theater nor radio or television station. Media communication depended on large, expensive structures usually linked to political power. But with mobile networks, hardware compression capabilities, and increasing performance, other functions have been assigned to the phone: shooting, filming, reproducing, and transmitting all sorts of data. It became the personal television, a pocket cinema, a direct contact with everything and everyone anywhere. Instant interconnection with other locations has become a trivial 
and inexpensive process. To transmit live video even of the banalest moments of life came to be part of the daily consumption and distribution of media inceptions.

\section{Perception and Participation}

13 We are amidst participatory culture where media spectators are no longer passive as Henry Jenkins observes: "Rather than talking about media producers and consumers occupying separate roles, we might see them as participants who interact with each other according to a new set of rules that none of us fully understand" (2006:3). These changes also bring upon opportunities to explore other territories of meaning, learning, contributing and dialoguing. Developing media skills helps the understanding of processes, flows, meanings and cultural characteristics within communicational environments. Mostra Goiás actions are thought consonantly with Bauer (2011), Ferrés and Piscitelli (2012) statements on the development of media competencies. Discussing the public value of media literacy, Thomas Bauer perceives it as "thought to be a specification of a general framework of communicative and cultural competencies to gain social capital" (Bauer, 2011: 17).

A narrative form of media, especially audiovisual communication, is also part of a temporal relationship integrated with society creating a new spatiotemporal perception and participation of contemporaneity. As Linda K. Fuller (2016: 12) argues, "participatory media, which draw on theories and practices of development, social change, and idealism, depend upon decision- making by the intended population - offering an openness with limitless potential for social- political expression(s)."

Mobile phones "swallowed" antennas, newsrooms, fleets of vehicles, geolocators and all sort of sensors and networks. On the digital environment, we are human beings full of "magical" features and tricks like the cartoons' characters. We live the "mediation of everything" - as Sonia Livingstone professes (2009:2): "in a heavily mediated world, one cannot analyze the relation between politics and the environment, or society and the family without also recognizing the importance of the media - all these spheres and their intersections have become mediated". Consequently, Stig Hjarvard conceptualized the mediatization of culture and society: "the aim is to consider whether and how structural changes between the media and the various social institution or cultural phenomena come to influence human imaginations, relationships, and interactions" (Hjavard 2013:3). In this context, this program seeks to empower students to deal with media languages and with new social, cultural, political and territorial dynamics.

People who do not master audiovisual and/or photography languages are at a disadvantage as to those who are "fluent" in photo or video. Digital media permeate the actions of interacting, interpreting or performing daily life. Living requires some of the skills of the digital media and territories to deal with family, friends, co-workers, financial systems and governances. These skills are not always equaled or even assimilated, neither is the accesses to mobile phones and mobile data networks democrat in most countries - according to ITU statistics. However, digital culture has already marked a significant change in communication and interculturality and the perceptions of media as a means of social and political changes. 


\section{Affinity Groups}

17 Another characteristic of this action-research is the organization of activities by themes and affinity groups. By teams of four students, they research and produce videos on traditional cultures like Catira, Congada, Folia de Reis and local foods, dialects, fashion, architecture, music and other forms of arts and culture. For video production research, students need to seek out information about the communities, artists or cultural manifestations of the place where they live. Affinity and empathy for local or traditional cultures determine whether to approve the themes proposed for the videos.

James Paul Gee (2003) studies affinity groups to explain phenomena of video game players that come together in the understanding and disputes. Gee disagrees on what some authors call "communities of practices" because for him affinity groups have "common challenges" which are organized in "whole processes", and so the members participate with "extensive knowledge" because they need to integrate into processes of these "common challenges." Also, Delabastita (1989:196) assets that "unlike communication through books, radio, telephone, or sign language, audiovisual communication implies that both the acoustic channel through air vibration and the visual channel through light waves are simultaneously utilized."

19 The students were instructed to use the grammar of classical movies: basic framing (close, medium and long shots) and smooth camera movements. As David Bordwell (2013: 158) assigns Hollywood narration demarcates its scenes by neoclassical criteria - unity of time (continuous or consistently intermittent duration), space (a definable locale), and action (a distinct cause-effect phase). The bounds of the sequence will be marked by some standardized punctuations (dissolve, wipe, fade, sound bridge). By standardizing the procedure of shots and camera movements, the pupils could achieve sufficient quality to present the material in TV, theater, and social networks.

20 When a group of students approves the content for presentation in the local cinema and television schedules, they also prove to themselves that can get into the established media gear with audiovisual material made with cell phones. Something made possible from the observation of the simplicity of the methods of montage, the distribution and the exhibition of the classic film industry.

21 As examples, there is the family that tells in "Memórias do Biscoito Cascudo" the story of a great sales biscuit in downtown Goiânia in the 1950s and 1960s; or how the Colombian families of street artists live and have their interactions in Goiânia. There is still the family that opens the house to show how everyone comes together to make pamonha, a typical dish of the region. People and situations are presented with a more interested and identified look with some information about the neighborhoods where the "reporters/ filmmakers" live. The artistic, architectural, cultural and sexual diversities of the State of Goiás are portrayed in the videos. Thus, there is visibility for the people of urban cultures, religions, traditional festivals and many other aspects of Goiás' cultures such as rap, hiphop, queer, rock, street dance, theater, graffiti and so on. 


\section{Conclusion}

The first experimental videos were presented at Goiânia Ouro Cinema. Being on display at the local cinema circuit, the videos were also listed on the cultural section of the local press. In addition to thousands of hits on social networks, the actions of the students also generated spontaneous reports in the traditional press. Only in 2014, there were 4,1m2 calls in major newspapers in the state of Goiás, and more than three hundred minutes with the sum of interviews and videos presented on statewide television stations. An example that can be applied in schools of all levels, as it is already done as a research and extension program training anyone who want to participate in open classes at the Arts and Culture Coordination (CAC/ Proex) of PUC Goiás.

3 Jacques deLisle (2016:77) call actions like these as "new media empowerment" and classifies them in two ways: first, as a social media orientation that dissects the current social structure and social relations, and that is in the process of changing the power structure of society. In the second place, new media empowerment can be seen as media socialization that is in the course of reconstructing social relations and social structures. As Belinha S. De Abreu (2014:189) remarks, "in the lab, the digital media specialist can support critical thinking around media use and digital citizenship while working with classroom-aligned content to drive relevant productions designed to teach digital skills."

By presenting their works on movie theaters and television, students understand that they can explore other types of scopes and consolidate other audiences by combining the use of online social networks and other software. All material is stored at youtube.com/ mostragoias channel so that it can be shared in the different online social participation media. Through the university, the videos are also cataloged in the library and serve as support for research on the cultures of Goiás. The students' research on local and traditional cultures yields a pedagogical material that can soon be used by other students. Being published on the Internet also gives people living in other states or countries the convenience of learning about Goiás' cultures through videos. As Elodie Roy reminds, "once a piece of information becomes universally saved and captured in an external form, it ceases to be privately owned and subjectively experienced" (Roy, 2016: 180).

This research and extension program is based on the concepts of media competence for the training of students with different expertise and backgrounds. The results of this action research also serve as a model for other partnerships between governments, businesses, and universities for the promotion of local and/or traditional cultures. This proposal aims to collaborate with the enrichment of the news offer, to seek ways of approach and experience of the public through the production and exhibition of films; to create historical records, dialogues, and mobilization in social, physical or virtual environments. This postdoctoral research and extension program was carried out under the supervision of Ilana Strozenberg (PACC / UFRJ.br) and Àngel Rodríguez Bravo (Laicom / UAB.es), with whom I could observe the consonance and actions with other research and practices in Rio de Janeiro and Barcelona. It is also the result of a personal challenge of applying in academia and the community something of the 18-year experience dedicated to television and internet projects in Brazil and Spain. A seed for an expansion of the processes of creation and diffusion of local cultures, making use of media for positive reinforcement and more affective approaches regarding the cultures and spaces of coexistence - physical or immaterial. 


\section{BIBLIOGRAPHY}

Belinha S. de Abreu and Paul Mihailidis, (dir.), Media Literacy Education in Action, London, Routledge, 2014.

Bill Nichols, Introduction to Documentary, Bloomington, Indiana University Press, 2017.

David Bordwell, Narration in the fiction film, Madison, The University of Wisconsin Press, 2013.

David Tripp, “Action research: a methodological introduction”, Educação e Pesquisa, Vol. 31, n.3, p. $443-466,2005$

Dirk Delabastita, Translation and mass-communication: film and T.V - Translation as evidence of cultural dynamics, Babel, vol. 3 (n. 4), p. 193-218, 1989.

Elodie Roy, Media, Materiality and Memory: Grounding the Groove, New York, Routledge, 2016.

Henry Jenkins, Convergence Culture, New York, New York University Press, 2006.

Jacques Delisle, The Internet, Social Media, and Changing China. Philadelphia, University of Pennsylvania Press, 2016.

James Paul Gee, What Video Games Have to Teach Us about Learning and Literacy, Palgrave Macmillan, New York, 2003.

Joan Ferrés and Alejandro Piscitelli, "La competência mediática: propuesta articulada de dimensiones e indicadores", Comunicar, vol. XIX, n. 38, 2012, p. 75-82.

Linda K. Fuller, The Power of Global Community Media, New York, Palgrave Macmillan, 2012.

ITU, Measuring The Information Society Report 2016 https://www.itu.int/en/ITU-D/Statistics/ Documents/publications/misr2016/MISR2016-w4.pdf (accessed June, 2d 2017).

Scott Walden, (dir.), Photography and Philosophy: Essays on the pencils of nature, West Sussex, WileyBlackwell, 2010.

Stig Hjarvard, Mediatization of Culture and Society, Nova York, Routledge, 2013.

Sonia, Livingstone, On the mediation of everything, \{s.1.\}: ICA Presidential Adress, 2008. Thomas Bauer, O valor público do media literacy, Líbero, São Paulo, vol. 14 (n. 27), p. 9-22, 2011.

\section{ABSTRACTS}

"Mostra Goiás" is a postdoctoral research and extension program carried out at the Contemporary Advanced Culture Program at Federal University of Rio de Janeiro and LAICOM/ Autonomous University of Barcelona and developed at the Pontifical Catholic University of Goiás (Brazil). The program deals on how audiovisual language can be used to promote local cultures by creating historical registers connected to the venues of online networked systems. This media literacy project presents Goiás State's culture via mobile video reports done by students of Journalism, Archeology and community pupils. There are 87 short documentaries recorded on mobile phones shown on cinema and statewide TV as a pedagogical experience. Moreover then training audiovisual techniques, the students try information systems developed by online platforms and mobile applications. The authors of the videos had no previous experience in 
broadcasting any material in established media. By sharing fundamental processes and protocols, they can organize, produce and present media work.

"Mostra Goiás" es un programa de investigación y extensión postdoctoral realizado en el Programa Avanzado Cultura Contemporánea de la Universidad Federal de Río de Janeiro y LAICOM/Universidad Autónoma de Barcelona y desarrollado en la Pontificia Universidad de Goiás (Brasil). El programa trata sobre cómo el lenguaje audiovisual puede ser utilizado para promover culturas locales, creando registros históricos conectados a sistemas digitales en red. Este proyecto de alfabetización mediática presenta la cultura del Estado de Goiás en Brasil a través de reportes de video realizados por estudiantes de Periodismo, Arqueología y alumnos de la comunidad. Hay 87 documentales cortos grabados en teléfonos móviles presentados en cine y en televisión como una experiencia pedagógica. Además de entrenar técnicas de audiovisual, los estudiantes prueban sistemasdeinformaciónformadospor plataformas en línea y aplicaciones móviles. Los autores de los vídeos no tenían experiencia previa en la transmisión de material en medios establecidos. Compartiendo procesos y protocolos básicos, pudieron organizarse, producir y presentar trabajos mediáticos.

"Mostra Goiás" é um programa de pesquisa e extensão de pós-doutorado realizado no Programa Avançado de Cultura Contemporânea da Universidade do Rio de Janeiro e LAICOM/Universidade Autônoma de Barcelona e desenvolvido na Pontifícia Universidade Católica de Goiás. O programa trata de como a linguagem audiovisual pode ser usada para promover as culturas locais criando registros históricos conectados aos sistemas em rede on- line. Este projeto de media literacy apresenta a cultura do Estado de Goiás no Brasil por meio de vídeos feitos por estudantes de jornalismo, arqueologia e alunos da comunidade em geral. São 87 documentários gravados em celulares apresentados no cinema e na TV estadual como uma experiência pedagógica. Além de treinar técnicas de audiovisual, os alunos experimentam sistemas de informação formados por plataformas on-line e aplicativos de celulares. Os autores dos vídeos não tinham experiência anterior em transmissão de material em meios estabelecidos. Partilhando processos e protocolos básicos puderam organizar, produzir e apresentar trabalhos conjuntos de mídia.

\section{INDEX}

Keywords: media literacy, culture, mobile, audiovisual

Palabras claves: competencia mediática, cultura, móviles, audiovisual

Palavras-chave: alfabetização midiática, cultura, mobilidade, audiovisual

\section{AUTHOR}

\section{VIANA TEIXEIRA CÉSAR}

PUC Goiás, PACC/UFRJ.br and Laicom/UAB.es 